\title{
Water-Yield Relationships in Deficit Irrigated Onion
}

\author{
Serhat Ayas 1,a,* \\ ${ }^{I}$ Yenişehir İbrahim Orhan Vocational School, University of Uludağ, Yenişehir, 16059 Nilüfer/Bursa, Turkey \\ *Corresponding author
}

A R T I C L E I N F
Research Article

Received : 13/03/2019
Accepted : 10/07/2019

A B S T R A C T

This trial was realized in the greenhouses of Uludağ University Yenişehir Vocational School between 2009 and 2010 to investigate effects of water deficit on yield and quality parameters of onion during four crop growth stages. In this trial, fourteen irrigation treatments in four growth periods (establishment, vegetative, yield formation and ripening) of onion (Allium cepa L E.T Grano.502) were constituted and the yield and quality parameters found from these treatments were evaluated. The layout of the experiment was a completely randomized block design with three replications for each of the fourteen irrigation treatments tested. According to the content of the treatments, the irrigation amount water applied to the plants varied between 0 and $436 \mathrm{~mm}$ in the first year, and between 0 and $448 \mathrm{~mm}$ in the second year. Water consumption of onion in the first

Keywords: Evapotranspiration Crop yield response factor $(\mathrm{ky})$ WUE and IWUE values Quality parameters of onion Irrigation planning.

year ranged between 205 and $496 \mathrm{~mm}$ and in the second year ranged between 210 and $502 \mathrm{~mm}$. Yield, bulb weight, diameter, height and dry matter ratio were determined statistically significant. In 2009 and 2010 years, the maximum yield were found as $52.2 \mathrm{t} \mathrm{ha}^{-1}$ and $52.4 \mathrm{t} \mathrm{ha}^{-1}$ in $\mathrm{E}_{100} \mathrm{~V}_{100} \mathrm{Y}_{100} \mathrm{R}_{100}$ treatments, while the minimum yield were found as $0.8 \mathrm{tha}^{-1}$ and $0.5 \mathrm{t} \mathrm{ha}^{-1}$ in the $\mathrm{E}_{0} \mathrm{~V}_{0} \mathrm{Y}_{0} \mathrm{R}_{0}$ treatments, respectively. Water- yield relationship factors $\left(\mathrm{k}_{\mathrm{y}}\right)$ in 2009 and 2010 years were found as 1.03 and 1.04, respectively. The maximum WUE and IWUE values were obtained from establishment and ripening periods. Establishment and ripening periods may be suggested as the maximum efficient irrigation periods for the onion applied with drip irrigation under unheated greenhouse conditions.

\section{Introduction}

Decreases in water resources together with increasing impacts of global warming and climate changes and increasing demands of increasing population make effective utilization of water resources a must. Increasing demands of sectors also deplete the ground water resources, pollute water ecosystems and developing new water resources is getting more and more expensive each day. Since about $75 \%$ of water resources of Turkey is allocated for agricultural purposes, effective water utilization and water saving in irrigation are the most critical issues to be considered. Pressurized piped systems and especially drip irrigation should be widespread for effective water utilization in agriculture (Çakmak and Gökalp, 2011).

Van Straten et al. (2010), stated that the greenhousing is worldwide the fastest growing sector of all agricultural production activities. There are two essential causes for this. First, the plant grows in greenhouse differently from the external environment, in this way supplying some way of abri from the direct effect of the external air conditions. This allows the production of crops at that specific place. Second, the greenhouse allows to be produced of many crops. This situation permits the grower to direct the farming in a desirable aspect. It causes to higher crop yield, extended production period, better quality and less use of chemicals. The value added per unit surface area in greenhouse crops is much higher than that in field agriculture.

According to 2016 FAO data, dry onions were produced in 144 countries around the world and world total onion production was 90 million tons in 2016 year. China, India and Egypt are the world's three biggest onion producers with 23.9, 19.4, 3.0 million tons, respectively. India is the largest onion exporting country with 1.62 million tons. Turkey is one of the significant onion producer with Turkey 2120581 tons (sixth in the world) in the world. The onion production of Bursa province was around 85000 tons (Anonymous, 2016). 
The onion plant is native to Asia. Although it is cultivated in almost every part of our country, production is done intensively in Thrace region and Balıkesir, Bursa, Bandirma, Amasya, Corum, Tokat, Kastamonu, Hatay and Denizli. Onion is one of our vegetables which is of high economic importance which adds flavour to almost every food and it is of utmost importance in the nutrition of our country (Vural et al., 2000). Cooking bulbs are grown and consumed worldwide. They are known as Allium species and belong to the Alliaceae family. In this family, bulb onion (Allium cepa L.) or onion is the most common one in terms of cultivation and consumption (Günay, 2005).

Sezen (2005) found that surface irrigation is not suggested due to low irrigation efficiency originated from salinity and drainage problems in irrigated areas. On the other hand, excess water inputs and poor drainage, accompanied by traditional irrigation systems, lead to environmental problems such as salinization and water logging. The problems of conventional irrigation methods can be eliminated through the use of pressurized irrigation methods designed to ensure the efficient use of irrigation water in the field scale (Büyükcangaz et al., 2007). Thus, the use of less water consuming irrigation methods is of great importance with regard to irrigation planning (Anonymous, 2005).

The objectives of irrigation planning is to prevent the soil moisture level falling below the critical level for a specific crop and soil condition. This may enable to avoid the harmful effect of water stress by means of estimating the earliest date (Ritchie and Johnson, 1990). Irrigation planning with drip irrigation relies on approaches based on evapotranspiration estimations (Bar-Yosef and Sagiv, 1982; McNeeish et al., 1985; Clough et al., 1990; Hartz, 1993) and permissible soil-water depletion (Bogle et al., 1989). Ky represents the declines in the yield as a result of each deficit level in water consumption. $K y$ values usually difficult to create accurately. $K y$ values are affected by regional conditions, soil properties, crop physiology and cultural practices. A suggested $K y$ value for irrigation planning must be high enough to avoid the water stress caused by the needs and specific local situations. It remains low enough for effective water management (Yuan et al., 2003).

Some studies have been carried out to investigate the effect of deficit irrigation on onion (Orta and Şener, 2001; Kadayifci et al., 2005; Ayas and Demirtas, 2009). The purposes of this experiment were to obtain a prospectus for onion growers and to determine drip irrigated onion response to deficit irrigation regimes in Bursa province of Turkey.

\section{Material and Methods}

The trial was realized in Yenisehir Vocational School, Bursa in 2009 and 2010 years. For practical purposes, plastic greenhouse $(8 \mathrm{~m} \times 40 \mathrm{~m})$ was used. In the study place, winters are cold, and summers are hot. The average annual rainfall and temperature values for the region where the greenhouse experiments were made in 2009 and 2010 were 531.3-804.4 $\mathrm{mm}$ and $13.3-14.6^{\circ} \mathrm{C}$, respectively. While the average minimum temperature for 2009 and 2010 were $-3.6-(5.9)^{\circ} \mathrm{C}$ between January and December, the average maximum temperature in August was measured as 30.6 and $34.6^{\circ} \mathrm{C}$ (Anonymous, 2011a). Maximum and minimum temperature values in greenhouse during the plant growing period (91 days) were $38-38^{\circ} \mathrm{C}$ and $0.9-1.3^{\circ} \mathrm{C}$, respectively in $2009-2010$ years (Figure 1 and 2). The highest and lowest relative humidity values in greenhouse in 2009 and 2010 years were found as 88-87\% and $39-39 \%$, respectively (Figure 3 ). In addition, the highest and lowest radiation values in greenhouse in 20092010 years were measured as 1974-1542 W/m2 and 335$139 \mathrm{~W} / \mathrm{m}^{2}$, respectively (Figure 4) (Anonymous, 2011b).

The soil of study place was sandy clay and $\mathrm{pH}$ value of soil ranged between 7.86 and 8.05. The specific features of the soil are given in Table 1 .

Table 1 Some specific properties of the experimental soil

\begin{tabular}{l|cccccccc}
\hline $\begin{array}{c}\text { Soil Depth } \\
(\mathrm{cm})\end{array}$ & $\begin{array}{c}\text { Soil } \\
\text { Type }\end{array}$ & $\begin{array}{c}\text { Unit Weight } \\
\left(\mathrm{gr} \mathrm{cm}^{-3}\right)\end{array}$ & $\begin{array}{c}\text { Field } \\
\text { Capacity }(\%)\end{array}$ & $\begin{array}{c}\text { Wilting } \\
\text { Point }(\%)\end{array}$ & pH & $\begin{array}{c}\text { Total Salt } \\
(\%)\end{array}$ & $\begin{array}{c}\mathrm{CaCO}_{3} \\
(\%)\end{array}$ & $\begin{array}{c}\text { Organic } \\
\mathrm{Matter}(\%)\end{array}$ \\
\hline $0-30$ & SL & 1.34 & 29.73 & 21.74 & 7.99 & 0.037 & 16.5 & 2.92 \\
$30-60$ & SL & 1.37 & 27.26 & 19.37 & 8.04 & 0.031 & 29.5 & 1.39 \\
$60-90$ & SL & 1.58 & 33.92 & 23.72 & 7.86 & 0.034 & 31.5 & 1.08 \\
$90-120$ & SL & 1.50 & 36.30 & 27.73 & 8.05 & 0.032 & 33.0 & 0.94 \\
\hline
\end{tabular}

SL: Sandy Loam,

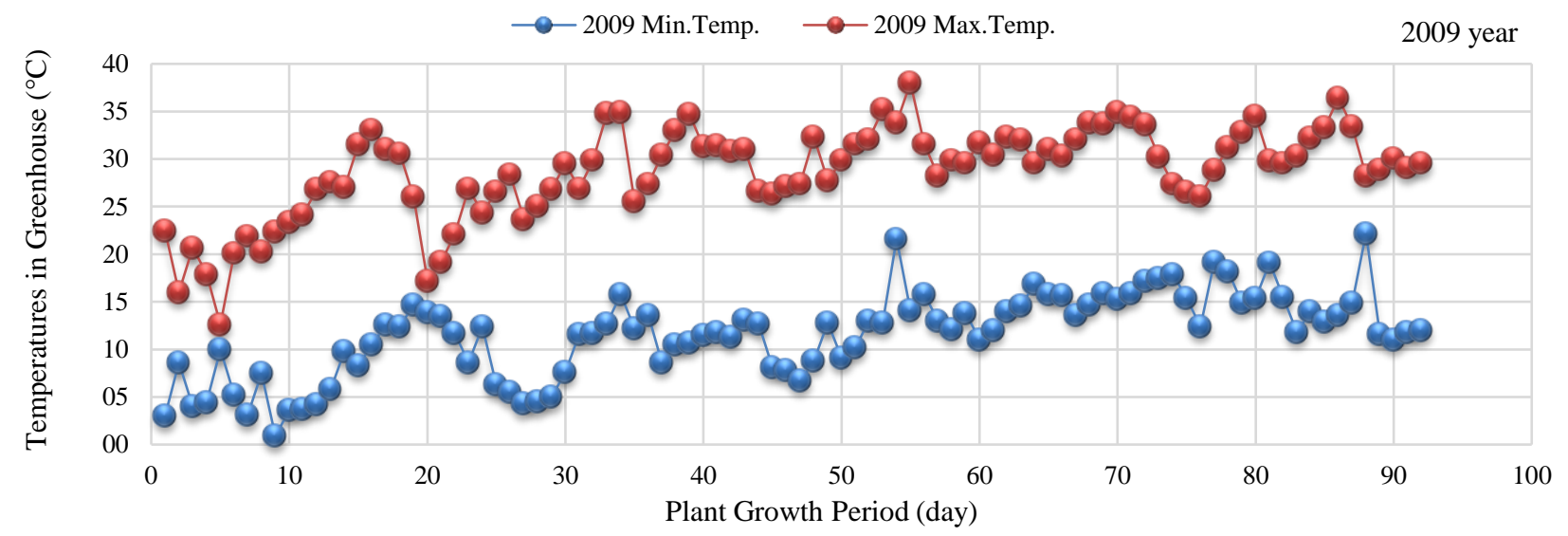

Figure 1 Temperatures in greenhouse during the plant growth period in 2009 year 


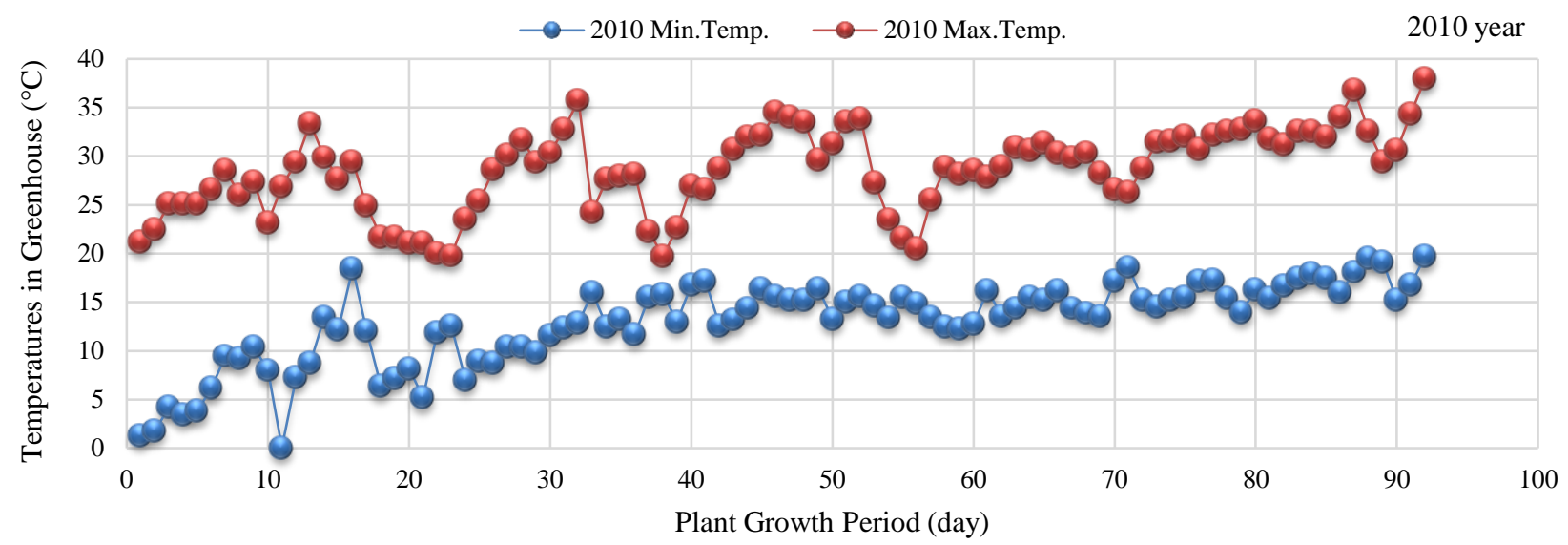

Figure 2 Temperatures in greenhouse during the plant growth period in 2010 year

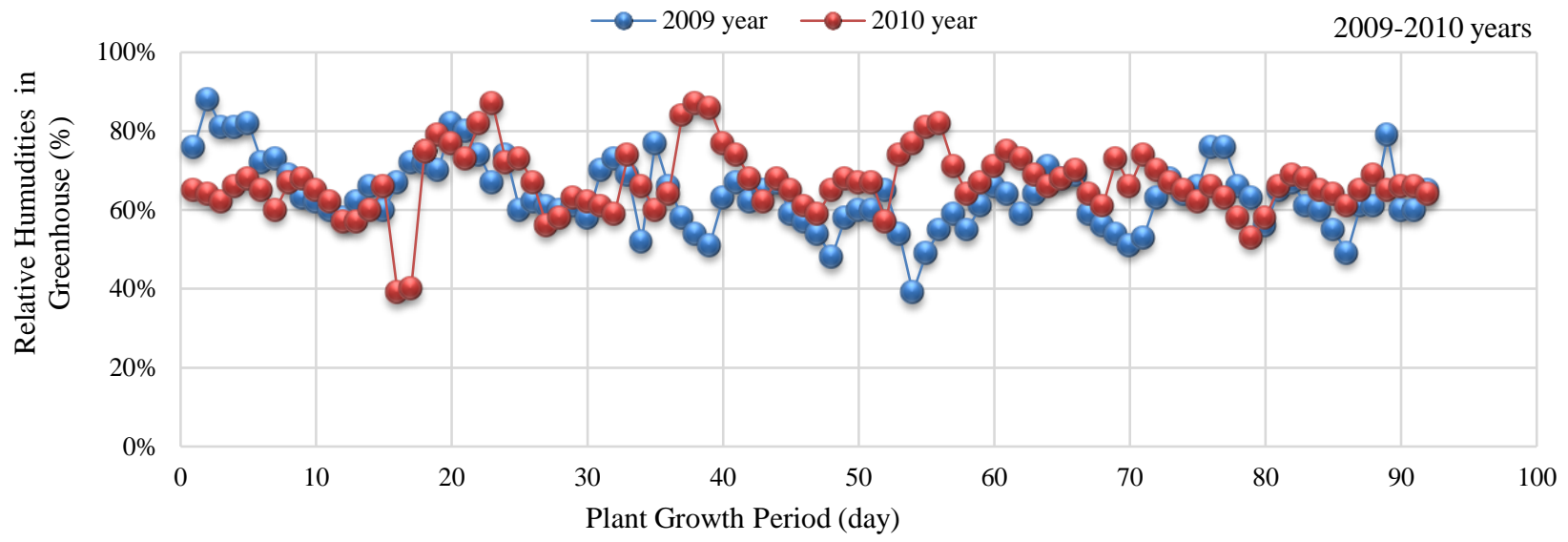

Figure 3 Relative humidity's in greenhouse during the plant growth period in 2009-2010 years

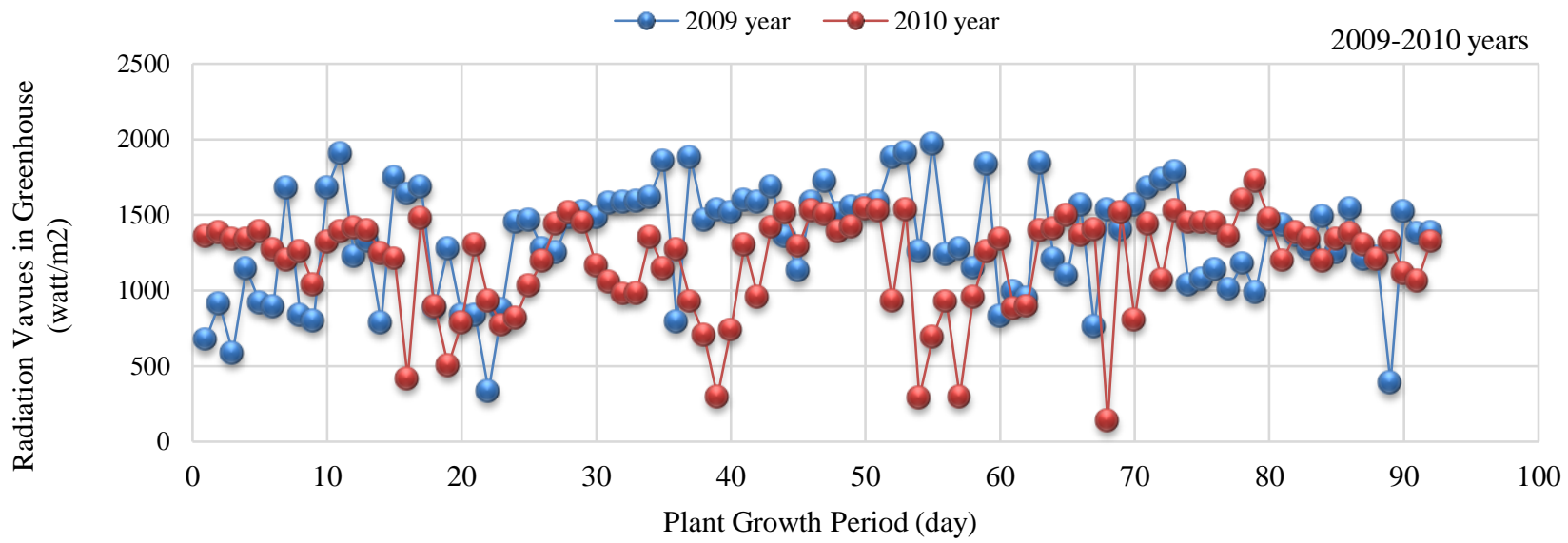

Figure 4 Radiation values in greenhouse during the plant growth period in 2009-2010 years

Yalova-15 variety was used in the study. This onion variety is white fleshy and its flavour is slightly bitter. Soluble solids content of onion is on average $14 \%$. The storage property is very good and its production happens with bulbs. The head shape of onion is long, the number of onionskin is 3-4 pieces and the colour of the onionskin is pink-brown. In the experimental area, an irrigation well was utilized as the source and the water was classified as $\mathrm{C}_{1} \mathrm{~S}_{1}$ after the analysis done. NPK $15-15-15$ fertilizer was sprinkled on the soil by hand before planting the seedlings as bottom fertilizer. The application depth of the fertilizer ranged from 15 to $20 \mathrm{~cm}$ depending on the soil structure and the root depth of the plant grown. NPK 15-15-15 fertilizer was utilized to trial plots while the onions were being planted, and $750 \mathrm{~kg}$ of NPK 15-15-15 fertilizer per hectares were utilized. The urea form of the nitrogen was applied to the plots together with the irrigation water. The first manure was applied as $250 \mathrm{~kg} / \mathrm{ha}(46 \% \mathrm{~N})$ in the flowering stage and the second fertilizer was utilized as $250 \mathrm{~kg} / \mathrm{ha}$ in yield formation stage together with the 
irrigation water. Furthermore, in 2009 and 2010 years, 250 $\mathrm{kg}$ of magnesium nitrate manure per hectares $(11-0-0+$ $16 \mathrm{MgO}$ - Nitrogen $11 \%$ and $\mathrm{MgO} 16 \%$ ) were used in the flowering and early yield formation stages to support the generative development. In the greenhouse was sprayed 10 $\mathrm{L} \mathrm{ha}^{-1}$ chlorphtifos-ethyl to the onions for insects.

The plots of the randomized experimental design were formed with three repetitions and 14 trial treatments were randomly scattered. The size of the trial plots was $4 \mathrm{~m}^{2}(2.0$ $\mathrm{m} \times 2.0 \mathrm{~m}$ ). The distances between the plots were $0.80 \mathrm{~m}$ and blocks were placed with $1.5 \mathrm{~m}$ distances. The seeds were sown in small pot on 15 May 2009 and on 12 May 2010 in the experimental years. The onion seedlings were transplanted to the plots on 10 April 2009 and on 17 April 2010. The seedlings were grown with $10 \mathrm{~cm}$ intervals on the same line and with $20 \mathrm{~cm}$ intervals between the plant lines. Into each plot, 231 plants were planted.

The yield and quality parameters of onion are yield, fruit weight, diameter, height and dry matter ratio. The fruit weight was determined by weighting 45 plants in the harvest part and bulb diameter and height were calculated by gauging the weighted fruit with a scale/ruler and by taking the average of these values. The dry matter ratio was obtained after they were dried at $65^{\circ} \mathrm{C}$ in a drying oven for 48 hours and fruit dry matter ratio was calculated. The detail of the experimental plot is shown in Figure 5.

In different growth periods of the onion (Establishment $(\mathrm{E})$, vegetative $(\mathrm{V})$, yield formation $(\mathrm{Y})$ and ripening $(\mathrm{R})$ ) fourteen deficit irrigation treatments were formed depending on full or deficit irrigation applications. 75-50$25 \%$ of the deficit irrigations were applied in different growth stages of the plant (establishment, vegetative, yield formation and ripening), while $100 \%$ of irrigation water was used in full irrigation treatment. In line with this planning, irrigation treatments were planned like this: $\mathrm{E}_{100} \mathrm{~V}_{100} \mathrm{Y}_{100} \mathrm{R}_{100}, \mathrm{E}_{75} \mathrm{VYR}, \mathrm{E}_{50} \mathrm{VYR}, \mathrm{E}_{25} \mathrm{VYR}, \mathrm{EV}_{75} \mathrm{YR}$, $\mathrm{EV}_{50} \mathrm{YR}, \mathrm{EV}_{25} \mathrm{YR}, \mathrm{EVY}_{75} \mathrm{R}, \mathrm{EVY}_{50} \mathrm{R}, \mathrm{EVY}_{25} \mathrm{R}, \mathrm{EVYR}_{75}$, $\mathrm{EVYR}_{50}, \mathrm{EVYR}_{25}, \mathrm{E}_{0} \mathrm{~V}_{0} \mathrm{Y}_{0} \mathrm{R}_{0}$ (Table 2.).

The drip irrigation equipment in greenhouse used in the study was given in Figure 6.a and 6.b

In the trial, the plants were irrigated by drip irrigation method and water was provided from an irrigation well. Some features of the irrigation water were given in Table 3. The irrigation water has low-sodium risk and medium $\mathrm{EC}$ and its class in $\mathrm{C}_{2} \mathrm{~S}_{1}$ class. $\mathrm{C} 2 \mathrm{~S} 1$ irrigation water quality class has low sodium and medium electrical conductivity (salinity). Water in the C2S1 quality class can be used for be irrigated medium and highly resistant plants to salinity. In addition, C1S1 quality class water can be used in all plants and soil without creating harmful alkalinity. A study has been conducted on irrigating pepper by using C2S1 quality class water (Ashraf and Ewees, 2008).

In four growth period, the soil moisture contains of the soil was followed before and after irrigation with a gravimetric method in every $30 \mathrm{~cm}$ up to $120 \mathrm{~cm}$ depth.

Evapotranspiration (ET), was calculated with water balance equation (Eq. 1) (Howell et al., 1995).

$$
\mathrm{ET}=\mathrm{I}+\mathrm{P}-\mathrm{R}_{\mathrm{f}}-\mathrm{D}_{\mathrm{p}} \pm \Delta \mathrm{S}
$$

Where, ET represents the evapotranspiration, I shows the irrigation water amount during the period $(\mathrm{mm}), \mathrm{P}$ is the total precipitation, $\mathrm{R}_{\mathrm{f}}$ is the amount of the surface flow $(\mathrm{mm}), \mathrm{D}_{\mathrm{p}}$ indicates the deep drainage $(\mathrm{mm})$ and $\Delta \mathrm{S}$ is the soil water content at the beginning and end of the period $(\mathrm{mm} / 120 \mathrm{~cm})$. Before planting seedlings, water was given to the crop by drip irrigation method. Total precipitation (P) and surface flow $\left(\mathrm{R}_{\mathrm{f}}\right)$ were omitted due to the plant production in the greenhouse. The soil water in the deeper than $120 \mathrm{~cm}$ was taken as the deep drainage $\left(D_{p}\right)$ and the deep drainage (Dp) was neglected.

The intervals of lateral were equal to the plant row intervals in the trial. Therefore the percentage of wetted area was calculated by the equation as follows (2) (Güngör and Yıldırım, 1989).

$$
\mathrm{P}=\frac{\mathrm{Sd}}{\mathrm{Sl}} 100
$$

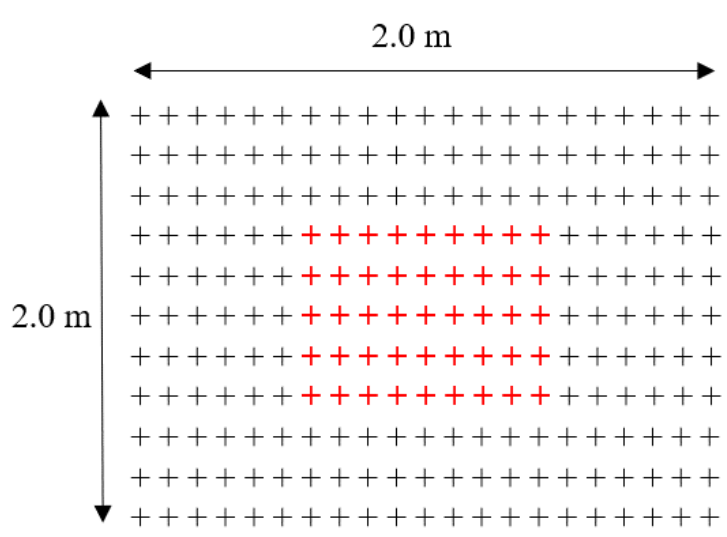

Figure 5 The detail of a plot

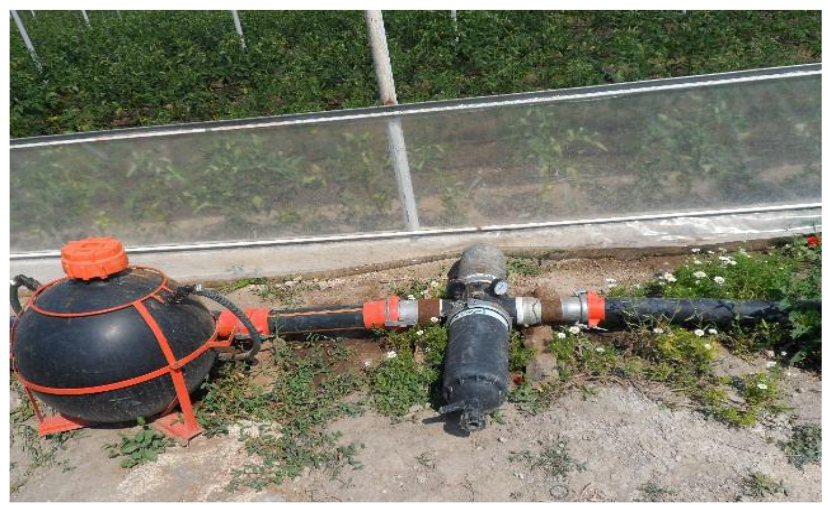

(a)

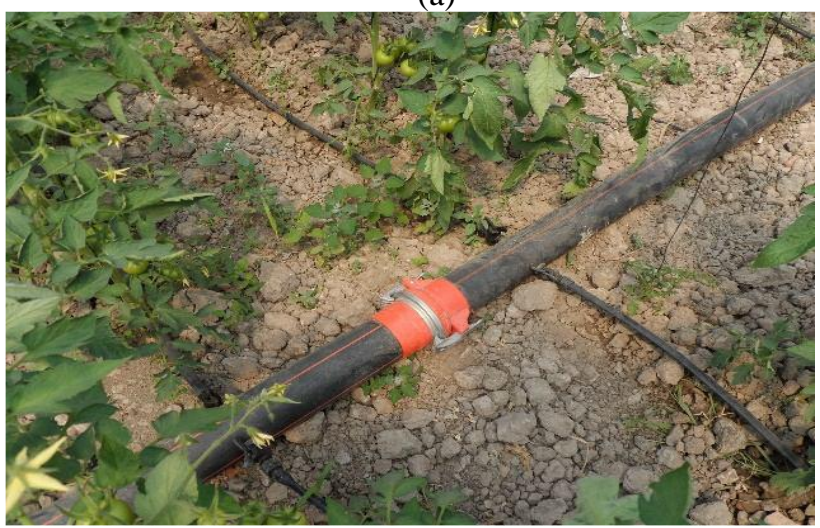

(b)

Figure 6 (a) Drip irrigation system, (b) Main and lateral pipes 
Table 2 The experimental treatments

\begin{tabular}{|c|c|c|c|c|}
\hline Irrigation & \multicolumn{4}{|c|}{ Growth Stages } \\
\hline Treatments & Establishment & Vegetative & Yield Formation & Ripening \\
\hline $\mathrm{E}_{100} \mathrm{~V}_{100} \mathrm{Y}_{100} \mathrm{R}_{100}$ & + & + & + & + \\
\hline $\mathrm{E}_{75} \mathrm{VYR}$ & $\% 25$ deficit irrigation & + & + & + \\
\hline $\mathrm{E}_{50} \mathrm{VYR}$ & $\% 50$ deficit irrigation & + & + & + \\
\hline $\mathrm{E}_{25} \mathrm{VYR}$ & $\% 75$ deficit irrigation & + & + & + \\
\hline $\mathrm{EV}_{75} \mathrm{YR}$ & + & $\% 25$ deficit irrigation & + & + \\
\hline $\mathrm{EV}_{50} \mathrm{YR}$ & + & $\% 50$ deficit irrigation & + & + \\
\hline $\mathrm{EV}_{25} \mathrm{YR}$ & + & $\% 75$ deficit irrigation & + & + \\
\hline $\mathrm{EVY}_{75} \mathrm{R}$ & + & + & $\% 25$ deficit irrigation & + \\
\hline $\mathrm{EVY}_{50} \mathrm{R}$ & + & + & $\% 50$ deficit irrigation & + \\
\hline $\mathrm{EVY}_{25} \mathrm{R}$ & + & + & $\% 75$ deficit irrigation & + \\
\hline $\mathrm{EVYR}_{75}$ & + & + & + & $\% 25$ deficit irrigation \\
\hline $\mathrm{EVYR}_{50}$ & + & + & + & $\% 50$ deficit irrigation \\
\hline $\mathrm{EVYR}_{25}$ & + & + & + & $\% 75$ deficit irrigation \\
\hline $\mathrm{E}_{0} \mathrm{~V}_{0} \mathrm{Y}_{0} \mathrm{R}_{0}$ & - & - & - & - \\
\hline
\end{tabular}

+: Water application in the specified period, -: Without irrigation

Table 3 Specific properties of irrigation water used in the trial

\begin{tabular}{|c|c|c|c|c|c|c|c|c|}
\hline Water & $\mathrm{FC}_{25} \times\left(10^{6}\right)$ & $\mathrm{Na}^{+}$ & $\mathrm{K}^{+}$ & $\mathrm{Ca}^{2+}$ & $\mathrm{Mg}^{2+}$ & \multirow{2}{*}{$\mathrm{pH}$} & \multirow{2}{*}{ Class } & \multirow{2}{*}{ SAR } \\
\hline Source & $\mathrm{CL}_{25} \times(10)$ & & & & & & & \\
\hline Deep well & 715 & 2.3 & 2.56 & 9.25 & 5.7 & 7.12 & $\mathrm{C}_{2} \mathrm{~S}_{1}$ & 0.85 \\
\hline
\end{tabular}

Table 4 The irrigation water applied for four growth stages

\begin{tabular}{|c|c|c|c|c|c|c|c|c|c|c|}
\hline \multicolumn{11}{|c|}{ Irrigation Water $(\mathrm{mm})$} \\
\hline \multirow{2}{*}{ Treatments } & \multicolumn{2}{|c|}{ Establishment } & \multicolumn{2}{|c|}{ Vegetative } & \multicolumn{2}{|c|}{ Yield Formation } & \multicolumn{2}{|c|}{ Ripening } & \multicolumn{2}{|c|}{ Total } \\
\hline & 2009 & 2010 & 2009 & 2010 & 2009 & 2010 & 2009 & 2010 & 2009 & 2010 \\
\hline E100V100Y100R100 & 80 & 80 & 140 & 148 & 160 & 160 & 56 & 60 & 436 & 448 \\
\hline E75VYR & 60 & 60 & 140 & 148 & 160 & 160 & 56 & 60 & 416 & 428 \\
\hline E50VYR & 40 & 40 & 140 & 148 & 160 & 160 & 56 & 60 & 396 & 408 \\
\hline E25VYR & 20 & 20 & 140 & 148 & 160 & 160 & 56 & 60 & 376 & 388 \\
\hline EV75YR & 80 & 80 & 105 & 111 & 160 & 160 & 56 & 60 & 401 & 411 \\
\hline EV50YR & 80 & 80 & 70 & 74 & 160 & 160 & 56 & 60 & 366 & 374 \\
\hline EV25YR & 80 & 80 & 35 & 37 & 160 & 160 & 56 & 60 & 331 & 337 \\
\hline EVY75R & 80 & 80 & 140 & 148 & 120 & 120 & 56 & 60 & 396 & 408 \\
\hline EVY50R & 80 & 80 & 140 & 148 & 80 & 80 & 56 & 60 & 356 & 368 \\
\hline EVY25R & 80 & 80 & 140 & 148 & 40 & 40 & 56 & 60 & 316 & 328 \\
\hline EVYR75 & 80 & 80 & 140 & 148 & 160 & 160 & 42 & 45 & 422 & 433 \\
\hline EVYR50 & 80 & 80 & 140 & 148 & 160 & 160 & 28 & 30 & 408 & 418 \\
\hline EVYR25 & 80 & 80 & 140 & 148 & 160 & 160 & 14 & 15 & 394 & 403 \\
\hline EOVOYOR0 & 0 & 0 & 0 & 0 & 0 & 0 & 0 & 0 & 0 & 0 \\
\hline
\end{tabular}

Where $\mathrm{P}$ is the percentage of wetted area, $\mathrm{Sd}$ and $\mathrm{Sl}$ are the interval of dripper and the intervals of lateral, respectively. The amount of irrigation water to be applied in each irrigation (Eq.3) was found by the equation given below.

$$
\mathrm{dn}=\frac{(\text { FC-WP)Ry }}{100} \mathrm{yt} \mathrm{D} \frac{\mathrm{P}}{100}
$$

Where dn is the amount of irrigation water to be applied in each irrigation, FC and WP are the field capacity and wilting point, respectively. $\mathrm{yt}$ is the soil bulk density, D is wetted soil depth, P is the percentage of wetted area. In this trial, the relationships between yield and ET was described by Steward Model (Eq.4) (Stewart et al., 1975; Doorenbos and Kassam, 1979). The equation can be given as;

$$
\left(1-\frac{Y a}{Y m}\right)=k y\left(1-\frac{E T a}{E T m}\right)
$$

Where $Y_{m}(t / h a)$ and $Y_{a}(t / h a)$ are maximum and actual yield, respectively, $\mathrm{ET}_{\mathrm{m}}(\mathrm{mm})$ and $\mathrm{ET}_{\mathrm{a}}(\mathrm{mm})$ are maximum and actual evapotranspiration, respectively. The yield response factor is shown as $\mathrm{k}_{\mathrm{y}}$. WUE values were determined to assess irrigation efficiency in treatments. WUE and IWUE terms refer to contribution of irrigation water to effective use of plant production stages (Bos, 1980). Water use efficiency (WUE) for each treatment was calculated as fruit yield divided by seasonal evapotranspiration (ET). Irrigation water use efficiency (IWUE) was predicted as (Zhang et al., 1999):

$$
\mathrm{IWUE}=\frac{(\mathrm{Y} 1-\mathrm{YNI})}{\mathrm{I}}
$$

Where $Y_{1}$ is bulb yield of irrigation treatments $\left(t\right.$ ha $\left.{ }^{-1}\right)$ and $Y_{N I}$ is the bulb yield of non-irrigation treatment $\left(\mathrm{t} \mathrm{ha}^{-1}\right)$ and $I$ is the amount of irrigation water $(\mathrm{mm})$. The water content of the soil till $120 \mathrm{~cm}$ depth was calculated before the seedlings were planted into the soil. Before starting 
irrigations, moisture level of the soil was completed to the level of field capacity in all treatments. Irrigation was started on May 15 in 2009 and May 12 in 2010 and it was repeated every 7 days. The irrigation water amounts for the four growth periods of onion were given in Table 4. Crop evapotranspiration for growth periods of onion were given in Table 5.
Yield and quality parameters were evaluated. Variance analysis of yield and quality parameters were evaluated according to LSD multiple comparison test $(\mathrm{P}<0.05)$. Variance analysis was done with the values of yield productivity and quality parameters by using MSTAT-C and MINITAB software (Steel and Torrie, 1980).

Table 5 Crop evapotranspiration for different growth stages

\begin{tabular}{|c|c|c|c|c|c|c|c|c|c|c|}
\hline \multicolumn{11}{|c|}{ Crop Evapotranspiration (mm) } \\
\hline \multirow{2}{*}{ Treatments } & \multicolumn{2}{|c|}{ Establishment } & \multicolumn{2}{|c|}{ Vegetative } & \multicolumn{2}{|c|}{ Yield Formation } & \multicolumn{2}{|c|}{ Ripening } & \multicolumn{2}{|c|}{ Total } \\
\hline & 2009 & 2010 & 2009 & 2010 & 2009 & 2010 & 2009 & 2010 & 2009 & 2010 \\
\hline E100V100Y100R100 & 70 & 70 & 176 & 172 & 180 & 182 & 70 & 78 & 496 & 502 \\
\hline E75VYR & 50 & 55 & 154 & 155 & 178 & 180 & 46 & 45 & 428 & 435 \\
\hline E50VYR & 56 & 53 & 151 & 152 & 175 & 176 & 43 & 51 & 425 & 432 \\
\hline E25VYR & 50 & 50 & 155 & 155 & 176 & 178 & 40 & 45 & 421 & 428 \\
\hline EV75YR & 53 & 57 & 165 & 165 & 173 & 179 & 49 & 47 & 440 & 448 \\
\hline EV50YR & 50 & 55 & 161 & 165 & 177 & 170 & 47 & 53 & 435 & 443 \\
\hline EV25YR & 48 & 52 & 156 & 158 & 174 & 174 & 51 & 52 & 429 & 436 \\
\hline EVY75R & 55 & 62 & 170 & 167 & 174 & 175 & 53 & 56 & 452 & 460 \\
\hline EVY50R & 55 & 53 & 164 & 167 & 170 & 175 & 55 & 58 & 444 & 453 \\
\hline EVY25R & 53 & 52 & 165 & 167 & 165 & 166 & 51 & 58 & 434 & 443 \\
\hline EVYR75 & 53 & 51 & 165 & 169 & 170 & 177 & 44 & 42 & 432 & 439 \\
\hline EVYR50 & 50 & 53 & 167 & 173 & 172 & 174 & 41 & 37 & 430 & 437 \\
\hline EVYR25 & 50 & 58 & 168 & 171 & 171 & 173 & 38 & 32 & 427 & 434 \\
\hline E0V0Y0R0 & 50 & 50 & 55 & 55 & 60 & 60 & 40 & 45 & 205 & 210 \\
\hline
\end{tabular}

\section{Results}

In both of the years, maximal irrigation water was found in $\mathrm{E}_{100} \mathrm{~V}_{100} \mathrm{Y}_{100} \mathrm{R}_{100}$ treatment as $436-448 \mathrm{~mm}$ and minimal irrigation water was found in $\mathrm{E}_{0} \mathrm{~V}_{0} \mathrm{Y}_{0} \mathrm{R}_{0}$ treatment as $0-0 \mathrm{~mm}$ respectively. Crop water use of onion $\left(\mathrm{ET}_{\mathrm{c}}\right)$ increased with the increment in the water amount. ET was found as 205-496 $\mathrm{mm}$ in 2009 and $210-502 \mathrm{~mm}$ in 2010 in $\mathrm{E}_{100} \mathrm{~V}_{100} \mathrm{Y}_{100} \mathrm{R}_{100}$ and $\mathrm{E}_{0} \mathrm{~V}_{0} \mathrm{Y}_{0} \mathrm{R}_{0}$ treatments, respectively. The irrigation water and yield values are given in Table 6 .

Crop water production functions ( $\mathrm{k}_{\mathrm{y}}$ and $\mathrm{R}^{2}$ values) obtained for each growth stage (Establishment (E), flowering (F), yield formation (Y), ripening (R)) and total growing season in 2009 and 2010 were given in Table 7.

Linear relationships between $\mathrm{ET}_{\mathrm{c}}$ with $\mathrm{Y}_{\mathrm{a}}$, and IW with $Y_{\mathrm{a}}$ were observed for 2009 year. The relationship equation is as follows; $Y_{a}=0.1861 E T_{c}-34.488$ with $R^{2}=0.91$ and $Y_{a}=0.1143 I W+2.9695$ with $R^{2}=0.96$ (Figure $7 \mathrm{a}$ and $7 \mathrm{~b}$ ). Linear relationships between $\mathrm{ET}_{\mathrm{c}}$ with $\left(\mathrm{Y}_{\mathrm{a}}\right)$, and IW with $\mathrm{Y}_{\mathrm{a}}$ were observed for 2010 year. The relationship equation is as follows; $Y_{a}=0.1874 E T_{c}-36.138$ with $R^{2}=0.93$ and $Y_{a}=0.1121 I W+2.9147$ with $R^{2}=0.96$ (Figure 7.a and 7.b).

When the results were taken into consideration, yield was substantially affected by irrigation applications (Figure 7.a and 7.b). The maximum values of yield were found as $52.2 \mathrm{t} \mathrm{ha}^{-1}$ and $52.4 \mathrm{t} \mathrm{ha}^{-1}$ in $\mathrm{E}_{100} \mathrm{~V}_{100} \mathrm{Y}_{100} \mathrm{R}_{100}$ treatment for 2009 and 2010 years, respectively (Table 8 and 9).

When $\mathrm{E}_{100} \mathrm{~V}_{100} \mathrm{Y}_{100} \mathrm{R}_{100}$ treatment was made comparison with the other irrigation treatments, yield losses were determined as $6.5 \%, 7.2 \%, 7.6 \%, 12.5 \%$, $13.5 \%, 14.2 \%, 17.3 \%, 19.2 \%, 21.4 \%, 6.5 \%, 7.2 \%, 7.9 \%$, and $6425.0 \%$ in 2009 and $7.4 \%, 8.0 \%, 8.7 \%, 12.7 \%$, $13.4 \%, 14.4 \%, 14.2 \%, 16.4 \%, 18.6 \%, 6.5 \%, 7.4 \%, 8.3 \%$ and $10380.0 \%$ in 2010 . In the trial, it was observed that deficit irrigation has a significant effect on yield and quality parameters at $\mathrm{P}<0.05$ level.
Linear relationships between $\mathrm{ET}_{\mathrm{c}}$ with $\mathrm{Y}_{\mathrm{a}}$, and IW with $\mathrm{Y}_{\mathrm{a}}$ were observed for 2009 year. The relationship equation is as follows; $Y_{a}=0.1861 E T_{c}-34.488$ with $R^{2}=0.91$ and $Y_{a}=0.1143 I W+2.9695$ with $R^{2}=0.96$ (Figure 7.a and 7.b). Linear relationships between $\mathrm{ET}_{\mathrm{c}}$ with $\left(\mathrm{Y}_{\mathrm{a}}\right)$, and IW with $\mathrm{Y}_{\mathrm{a}}$ were observed for 2010 year. The relationship equation is as follows; $Y_{a}=0.1874 E T_{c}-36.138$ with $R^{2}=0.93$ and $Y_{a}=0.1121 I W+2.9147$ with $R^{2}=0.96$ (Figure 7.a and 7.b).

While a positive straight line relationship was obtained between the water amount and the yield, bulb weight, diameter, height; a negative straight line relationship was obtained between the irrigation amount and dry matter ratio. As for that the relationship, these results were determined: bulb weight $(2009)=0.2391 \mathrm{~W}+18.457, R^{2}=$ 0.89 and bulb weight $(2010)=0.2508 I W+17.78, R^{2}=0.92$ (Figure 8.a.); bulb diameter $(2009)=0.0121 I W+0.8005$, $R^{2}=0.89$ and bulb diameter $(2010)=0.0126 I W+0.6794$, $R^{2}=0.92$ (Figure 8.b).

\section{Crop Yield Response Factor $\left(k_{y}\right)$}

A straight line between relative crop evapotranspiration and relative yield decrease represents crop yield response factor $(k y)$. It indicates the response of the yield to the relative crop evapotranspiration. In another saying, it represents the declines in the yield as a result of each deficit level in water consumption. Seasonal crop yield response factors ( $k y)$ were determined as 1.03 (2009 year) and 1.04 (2010 year) (Figure 9). Ky value increased with the increase in the water deficit. This result was relatively small with regard to seasonal crop yield response factors in four different crop growth stages of the onions, while it was consistent with the crop yield response factors in each growth factors given in literature. The difference between these two results may refer to the differences between the empirical, climatic and bulb quality conditions. 
Table 6 Relationship between the decrease in water use, in yield and yield response factor (ky) for onion in 2009 and 2010 years.

\begin{tabular}{|c|c|c|c|c|c|c|c|c|c|}
\hline Irrigation Treatment & $\mathrm{Y}$ & AW & $\mathrm{E}$ & $\mathrm{E} / \mathrm{E}$ & $\mathrm{Y} / \mathrm{Y}$ & $1-\mathrm{E} / \mathrm{E}$ & $1-\mathrm{Y} / \mathrm{Y}$ & ky & ky \\
\hline E100V100Y100R100 & 52.2 & 436 & 496 & 1.000 & 1.000 & 0.000 & 0.000 & 0.000 & 0.000 \\
\hline E75VYR & 49.0 & 416 & 428 & 0.863 & 0.939 & 0.137 & 0.061 & 0.447 & \\
\hline E50VYR & 48.7 & 396 & 425 & 0.857 & 0.933 & 0.143 & 0.067 & 0.468 & 0.461 \\
\hline E25VYR & 48.5 & 376 & 421 & 0.849 & 0.929 & 0.151 & 0.071 & 0.469 & \\
\hline EV75YR & 46.4 & 401 & 440 & 0.887 & 0.889 & 0.113 & 0.111 & 0.984 & \\
\hline EV50YR & 46.0 & 366 & 435 & 0.877 & 0.881 & 0.123 & 0.119 & 0.966 & 0.957 \\
\hline EV25YR & 45.7 & 331 & 429 & 0.865 & 0.875 & 0.135 & 0.125 & 0.922 & \\
\hline EVY75R & 44.5 & 396 & 452 & 0.911 & 0.852 & 0.089 & 0.148 & 1.663 & \\
\hline EVY50R & 43.8 & 356 & 444 & 0.895 & 0.839 & 0.105 & 0.161 & 1.535 & 1.536 \\
\hline EVY25R & 43.0 & 316 & 434 & 0.875 & 0.824 & 0.125 & 0.176 & 1.410 & \\
\hline EVYR75 & 49.0 & 422 & 432 & 0.871 & 0.939 & 0.129 & 0.061 & 0.475 & \\
\hline EVYR50 & 48.7 & 408 & 430 & 0.867 & 0.933 & 0.133 & 0.067 & 0.504 & 0.501 \\
\hline EVYR25 & 48.4 & 394 & 427 & 0.861 & 0.927 & 0.139 & 0.073 & 0.523 & \\
\hline \multirow[t]{2}{*}{ E0V0Y0R0 } & 0.8 & 0 & 205 & 0.413 & 0.015 & 0.587 & 0.985 & 1.678 & 1.678 \\
\hline & & & & & & & & & 1.03 \\
\hline Irrigation Treatment & $\bar{Y}$ & $\mathrm{AW}$ & $\mathrm{E}$ & $\bar{E} / \mathrm{E}$ & $\mathrm{Y} / \mathrm{Y}$ & $1-\mathrm{E} / \mathrm{E}$ & $1-\mathrm{Y} / \mathrm{Y}$ & ky & ky \\
\hline E100V100Y100R100 & 52.4 & 448 & 502 & 1.000 & 1.000 & 0.000 & 0.000 & 0.000 & 0.000 \\
\hline E75VYR & 48.8 & 428 & 435 & 0.867 & 0.931 & 0.133 & 0.069 & 0.515 & \\
\hline E50VYR & 48.5 & 408 & 432 & 0.861 & 0.926 & 0.139 & 0.074 & 0.534 & 0.531 \\
\hline E25VYR & 48.2 & 388 & 428 & 0.853 & 0.920 & 0.147 & 0.080 & 0.544 & \\
\hline EV75YR & 46.5 & 411 & 448 & 0.892 & 0.887 & 0.108 & 0.113 & 1.047 & \\
\hline EV50YR & 46.2 & 374 & 443 & 0.882 & 0.882 & 0.118 & 0.118 & 1.007 & 1.004 \\
\hline EV25YR & 45.8 & 337 & 436 & 0.869 & 0.874 & 0.131 & 0.126 & 0.958 & \\
\hline EVY75R & 45.9 & 408 & 460 & 0.916 & 0.876 & 0.084 & 0.124 & 1.483 & \\
\hline EVY50R & 45 & 368 & 453 & 0.902 & 0.859 & 0.098 & 0.141 & 1.447 & 1.420 \\
\hline EVY25R & 44.2 & 328 & 443 & 0.882 & 0.844 & 0.118 & 0.156 & 1.331 & \\
\hline EVYR75 & 49.2 & 433 & 439 & 0.875 & 0.939 & 0.125 & 0.061 & 0.487 & \\
\hline EVYR50 & 48.8 & 418 & 437 & 0.875 & 0.931 & 0.125 & 0.069 & 0.547 & 0.533 \\
\hline EVYR25 & 48.4 & 403 & 434 & 0.865 & 0.924 & 0.135 & 0.076 & 0.564 & \\
\hline \multirow[t]{2}{*}{ EOV0Y0R0 } & 0.5 & 0 & 210 & 0.418 & 0.010 & 0.582 & 0.990 & 1.703 & 1.703 \\
\hline & & & & & & & & & 1.04 \\
\hline
\end{tabular}

Y: Yield (t ha $\left.{ }^{-1}\right)$, AW: Applied Water (mm), E: ETa (mm), E/E: ETa/ETm, Y/Y: Ya/Ym,

Table 7 Crop water production functions obtained for each growth stage and total growing season in 2009 and 2010 years

\begin{tabular}{l|ll}
\hline Year & \multicolumn{1}{|c}{ Period } & \multicolumn{1}{c}{ Production Functions } \\
\hline \multirow{3}{*}{2009} & $\mathrm{E}$ & $(1-\mathrm{Ya} / \mathrm{Ym})=0.46, \mathrm{R}^{2}=0.9616$ \\
& $\mathrm{~V}$ & $1-(\mathrm{Ya} / \mathrm{Ym})=0.96, \mathrm{R}^{2}=0.9820$ \\
& $\mathrm{Y}$ & $1-(\mathrm{Ya} / \mathrm{Ym})=1.54, \mathrm{R}^{2}=0.9993$ \\
& $\mathrm{R}$ & $1-(\mathrm{Ya} / \mathrm{Ym})=0.50, \mathrm{R}^{2}=0.9868$ \\
& Seasonal & $1-(\mathrm{Ya} / \mathrm{Ym})=1.03, \mathrm{R}^{2}=0.9129$ \\
\hline \multirow{3}{*}{2010} & $\mathrm{E}$ & $(1-\mathrm{Ya} / \mathrm{Ym})=0.53, \mathrm{R} 2=0.9932$ \\
& $\mathrm{~V}$ & $1-(\mathrm{Ya} / \mathrm{Ym})=1.00, \mathrm{R}^{2}=0.9998$ \\
& $\mathrm{Y}$ & $1-(\mathrm{Ya} / \mathrm{Ym})=1.42, \mathrm{R}^{2}=0.9818$ \\
& $\mathrm{R}$ & $1-(\mathrm{Ya} / \mathrm{Ym})=0.53, \mathrm{R}^{2}=0.9868$ \\
& Seasonal & $1-(\mathrm{Ya} / \mathrm{Ym})=1.04, \mathrm{R}^{2}=0.9289$ \\
\hline
\end{tabular}

Table 8 Effects of irrigation treatments on yield parameters of onion in 2009 year.

\begin{tabular}{|c|c|c|c|c|c|}
\hline Irrigation Treatment & Yield $\left(\mathrm{t} \mathrm{ha}^{-1}\right)$ & Bulb Weight (g) & Bulb Diameter $(\mathrm{cm})$ & Bulb Height $(\mathrm{cm})$ & Dry Matter (\%) \\
\hline E100V100Y100R100 & $52.2^{\mathrm{a}}$ & $134.0^{\mathrm{a}}$ & $6.6^{\mathrm{a}}$ & $7.0^{\mathrm{a}}$ & $9.8^{f}$ \\
\hline E75VYR & $49.0^{\mathrm{b}}$ & $120.0^{\mathrm{bc}}$ & $6.1^{\mathrm{abc}}$ & $6.4^{\mathrm{b}}$ & $10.0^{\mathrm{f}}$ \\
\hline E50VYR & $48.7^{\mathrm{b}}$ & $117.0^{\mathrm{cd}}$ & $5.9^{\mathrm{bc}}$ & $6.3^{\mathrm{b}}$ & $10.3^{\text {ef }}$ \\
\hline E25VYR & $48.5^{b}$ & $113.0^{\mathrm{ef}}$ & $5.6^{\text {cde }}$ & $6.1^{\mathrm{b}}$ & $10.6^{\text {def }}$ \\
\hline EV75YR & $46.4^{c}$ & $96.0^{\mathrm{h}}$ & $4.7^{\mathrm{gh} 1}$ & $5.2^{\mathrm{de}}$ & $10.8^{\text {def }}$ \\
\hline EV50YR & $46.0^{\mathrm{cd}}$ & $90.0^{1}$ & $4.5^{\mathrm{h} 1}$ & $4.9^{\text {ef }}$ & $11.2^{\text {cdef }}$ \\
\hline EV25YR & $45.7^{\mathrm{d}}$ & $85.0^{\mathrm{j}}$ & $4.2^{1}$ & $4.5^{\mathrm{f}}$ & $11.6^{\text {bcde }}$ \\
\hline EVY75R & $44.5^{\mathrm{e}}$ & $120.0^{\mathrm{bc}}$ & $5.3^{\mathrm{def}}$ & $5.5^{\mathrm{cd}}$ & $12.0^{\mathrm{bcd}}$ \\
\hline EVY50R & $43.8^{f}$ & $112.0^{\mathrm{ef}}$ & $5.1^{\text {efg }}$ & $5.2^{\mathrm{de}}$ & $12.5^{\mathrm{bc}}$ \\
\hline EVY25R & $43.0^{\mathrm{g}}$ & $103.0^{\mathrm{g}}$ & $4.8^{\text {fgh }}$ & $5.0^{\mathrm{def}}$ & $13.0^{\mathrm{b}}$ \\
\hline EVYR75 & $49.0^{\mathrm{b}}$ & $122.0^{\mathrm{b}}$ & $6.3^{\mathrm{ab}}$ & $6.5^{\mathrm{ab}}$ & $10.6^{\mathrm{def}}$ \\
\hline EVYR50 & $48.7^{\mathrm{b}}$ & $115.0^{\text {de }}$ & $6.1^{\mathrm{abc}}$ & $6.3^{\mathrm{b}}$ & $10.9^{\text {def }}$ \\
\hline EVYR25 & $48.4^{\mathrm{b}}$ & $110.0^{\mathrm{f}}$ & $5.8^{\mathrm{bcd}}$ & $6.0^{\mathrm{bc}}$ & $11.0^{\text {cdef }}$ \\
\hline EOVOYOR0 & $0.8^{\mathrm{h}}$ & $20.0^{\mathrm{k}}$ & $1.0^{\mathrm{j}}$ & $1.0^{\mathrm{g}}$ & $16.0^{\mathrm{a}}$ \\
\hline Treatments & $*$ & $*$ & $*$ & $*$ & $*$ \\
\hline Blocks & ns & ns & ns & ns & ns \\
\hline
\end{tabular}

** means correlation is significant at the 0.005 level. ns shows non-significant correlation. 


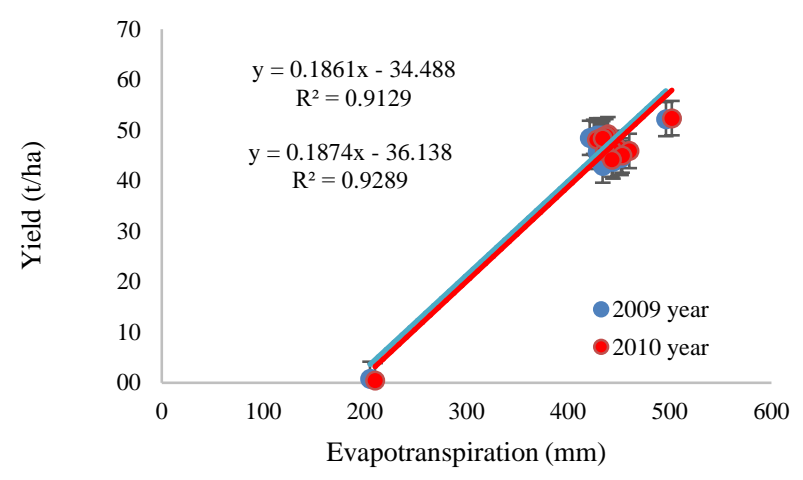

(a)

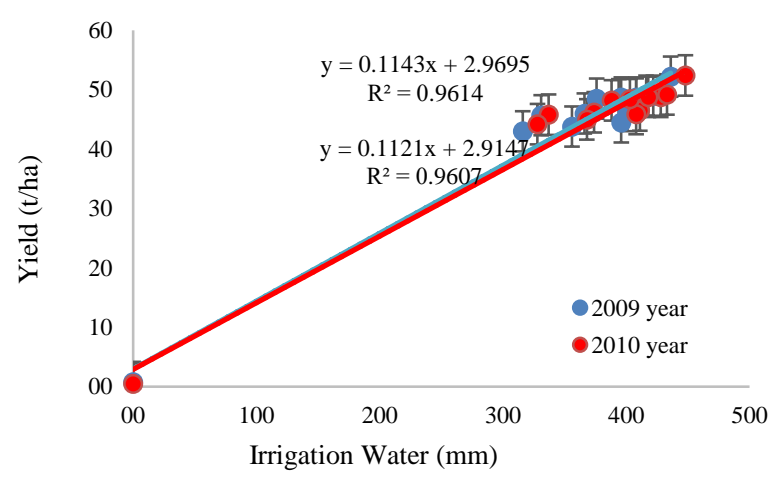

(b)

Figure $7 \mathrm{a}$ The relationship between crop water consumption and yield. $7 \mathrm{~b}$ The relationship between irrigation water and yield

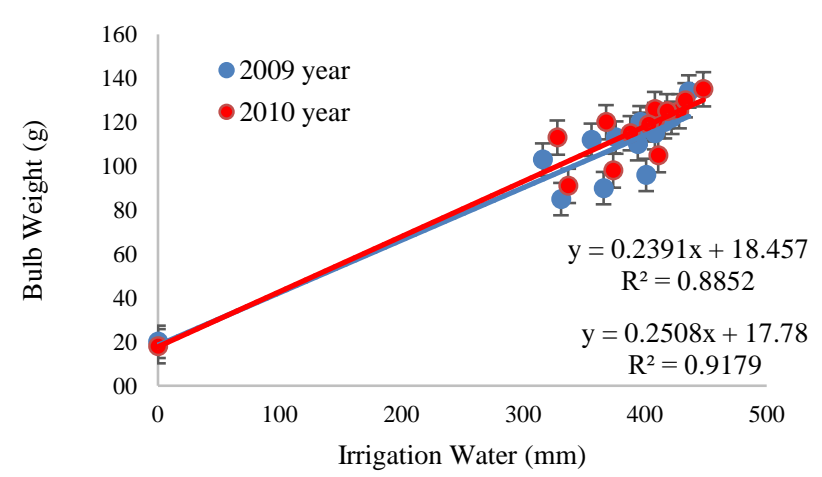

(a)

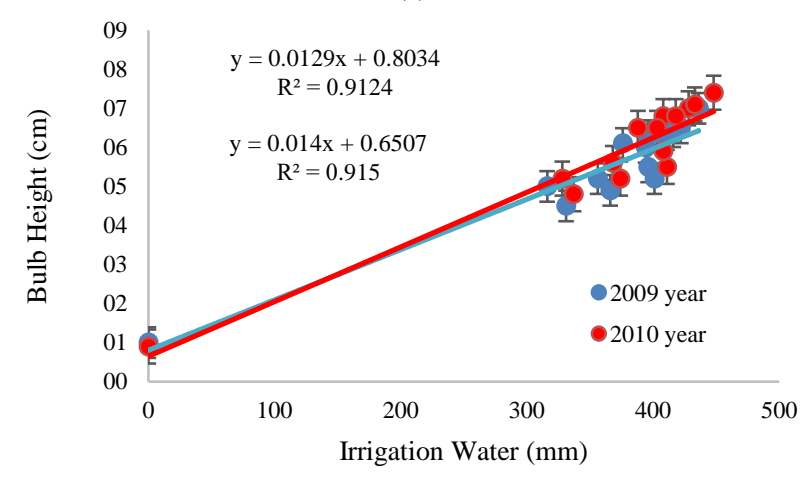

(c)

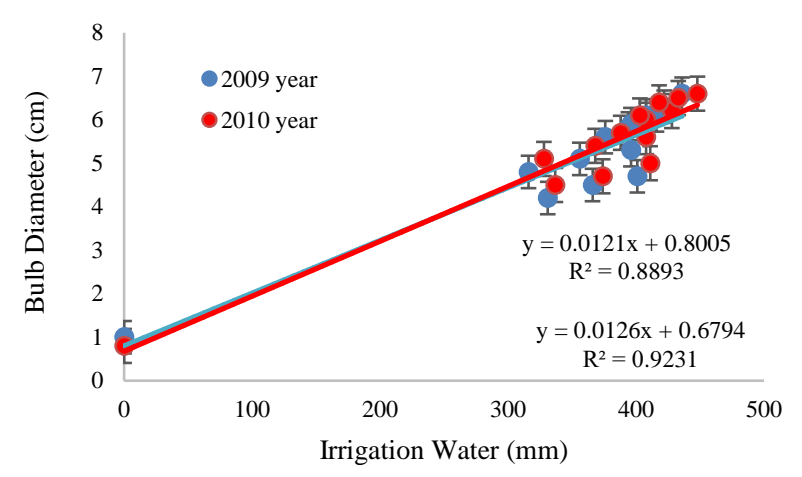

(b)

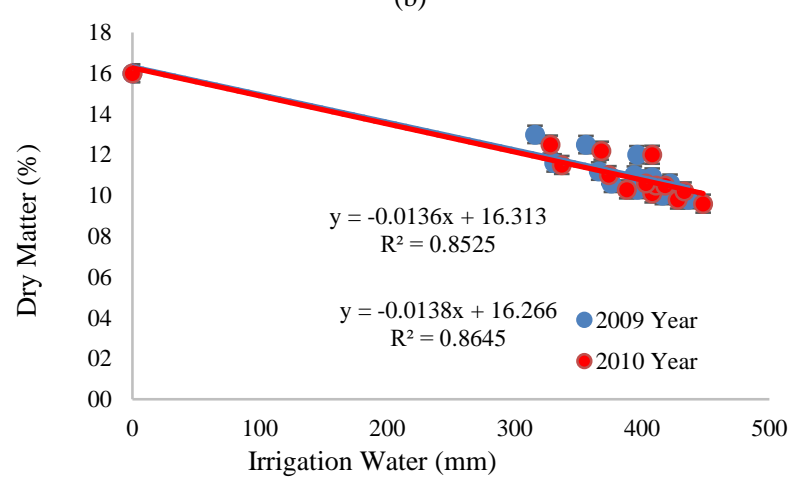

(d)

Figure 8 Relationship between irrigation water and fruit weight, diameter, height and dry matter ratio.

Bulb height (2009) $=0.0129 I W+0.8034, R^{2}=0.91$ and bulb height $(2010)=0.014 I W+0.6507, R^{2}=0.92$ (Figure 8c.); dry matter ratio (2009) $=$ $0.0136 I W+16.313, R^{2}=0.85$ and dry matter ratio $(2010)=-0.0138 I W+16.266, R^{2}=0.86$ (Figure $8 d$.).

Table 9 Effects of irrigation treatments on yield parameters of onion in 2010 year.

\begin{tabular}{|c|c|c|c|c|c|}
\hline Irrigation Treatment & Yield $\left(\mathrm{t} \mathrm{ha}^{-1}\right)$ & Bulb Weight (g) & Bulb Diameter $(\mathrm{cm})$ & Bulb Height $(\mathrm{cm})$ & Dry Matter $(\%)$ \\
\hline E100V100Y100R100 & $52.4^{\mathrm{a}}$ & $135.0^{\mathrm{a}}$ & $6.6^{\mathrm{a}}$ & $7.4^{\mathrm{a}}$ & $9.6^{\mathrm{f}}$ \\
\hline E75VYR & $48.8^{\mathrm{bc}}$ & $125.0^{\mathrm{bcd}}$ & $6.2^{\mathrm{ab}}$ & $7.0^{\mathrm{abc}}$ & $9.8^{\mathrm{ef}}$ \\
\hline E50VYR & $48.5^{\mathrm{bc}}$ & $121.0^{\text {cde }}$ & $6.0^{\mathrm{abc}}$ & $6.8^{\mathrm{bc}}$ & $10.1^{\mathrm{ef}}$ \\
\hline E25VYR & $48.2^{\mathrm{c}}$ & $115.0^{\text {ef }}$ & $5.7^{\mathrm{bcd}}$ & $6.5^{\mathrm{c}}$ & $10.3^{\text {def }}$ \\
\hline EV75YR & $46.5^{\mathrm{d}}$ & $105.0^{\mathrm{g}}$ & $5.0^{\mathrm{ef}}$ & $5.5^{\mathrm{de}}$ & $10.5^{\mathrm{def}}$ \\
\hline EV50YR & $46.2^{\mathrm{d}}$ & $98.0^{\mathrm{h}}$ & $4.7^{\mathrm{f}}$ & $5.2^{\mathrm{ef}}$ & $11.0^{\text {cde }}$ \\
\hline EV25YR & $45.8^{\text {de }}$ & $91.0^{1}$ & $4.5^{\mathrm{f}}$ & $4.8^{\mathrm{f}}$ & $11.5^{\mathrm{bcd}}$ \\
\hline EVY75R & $45.9^{\mathrm{d}}$ & $126.0^{\mathrm{bc}}$ & $5.6^{\text {bcde }}$ & $5.9^{\mathrm{d}}$ & $12.0^{\mathrm{bc}}$ \\
\hline EVY50R & $45.0^{\text {ef }}$ & $120.0^{\text {cde }}$ & $5.4^{\text {cde }}$ & $5.6^{\mathrm{de}}$ & $12.2^{\mathrm{bc}}$ \\
\hline EVY25R & $44.2^{\mathrm{f}}$ & $113.0^{\mathrm{f}}$ & $5.1^{\mathrm{def}}$ & $5.2^{\mathrm{ef}}$ & $12.5^{\mathrm{b}}$ \\
\hline EVYR75 & $49.2^{\mathrm{b}}$ & $130.0^{\mathrm{ab}}$ & $6.5^{\mathrm{a}}$ & $7.1^{\mathrm{ab}}$ & $10.2^{\mathrm{ef}}$ \\
\hline EVYR50 & $48.8^{\mathrm{bc}}$ & $125.0^{\mathrm{bcd}}$ & $6.4^{\mathrm{a}}$ & $6.8^{\mathrm{bc}}$ & $10.5^{\mathrm{def}}$ \\
\hline EVYR25 & $48.4^{\mathrm{bc}}$ & $119.0^{\text {def }}$ & $6.1^{\mathrm{ab}}$ & $6.5^{\mathrm{c}}$ & $10.6^{\text {def }}$ \\
\hline EOVOYORO & $0.5^{\mathrm{g}}$ & $18.0^{\mathrm{j}}$ & $0.8^{\mathrm{g}}$ & $0.9^{g}$ & $16.0^{\mathrm{a}}$ \\
\hline Treatments & $*$ & * & $*$ & $*$ & $*$ \\
\hline Blocks & ns & ns & ns & ns & ns \\
\hline
\end{tabular}




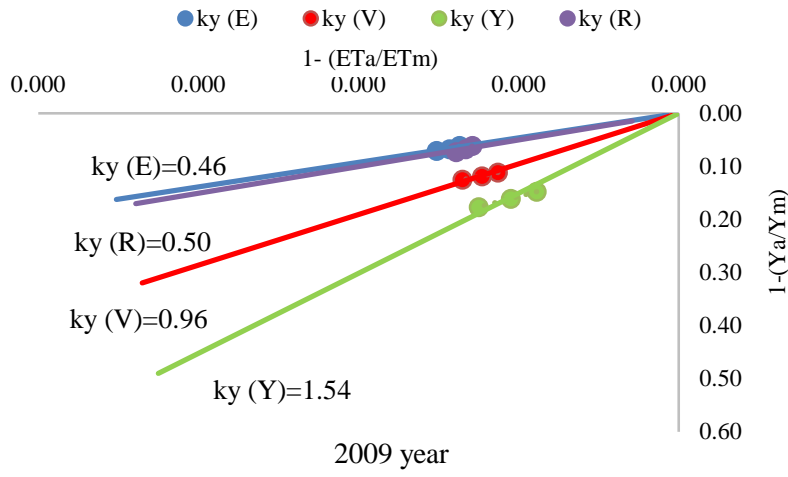

(a)

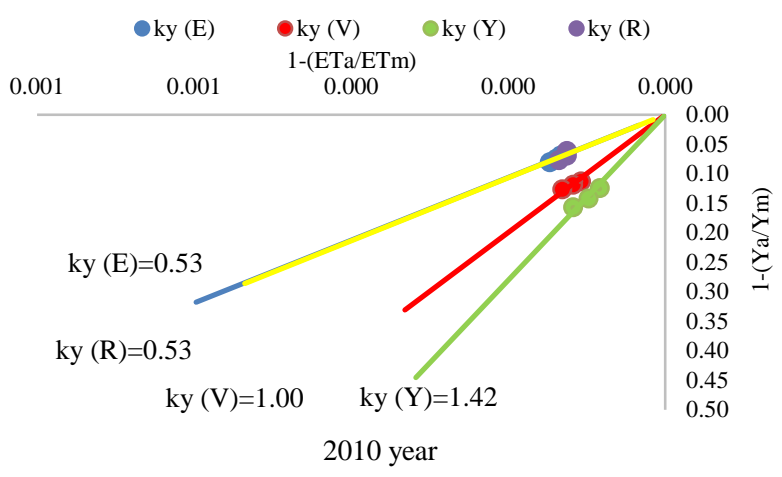

(b)

Figure 9 The relationship between relative yield decrease and relative evapotranspiration deficit for the experimental years

Table 10 WUE and IWUE values for the onion fourteen irrigation treatments.

\begin{tabular}{|c|c|c|c|c|c|c|c|}
\hline \multicolumn{4}{|c|}{2009} & \multicolumn{4}{|c|}{2010} \\
\hline Irrigation Treatment & $\begin{array}{c}\text { Yield } \\
\left(\mathrm{t} \mathrm{ha}^{-1}\right)\end{array}$ & $\begin{array}{c}\text { WUE } \\
\left(\mathrm{kg} / \mathrm{m}^{3}\right)\end{array}$ & $\begin{array}{l}\text { IWUE } \\
\left(\mathrm{kg} / \mathrm{m}^{3}\right)\end{array}$ & Irrigation Treatment & $\begin{array}{c}\text { Yield } \\
\left(\mathrm{t} \mathrm{ha}^{-1}\right)\end{array}$ & $\begin{array}{c}\text { WUE } \\
\left(\mathrm{kg} / \mathrm{m}^{3}\right)\end{array}$ & $\begin{array}{l}\text { IWUE } \\
\left(\mathrm{kg} / \mathrm{m}^{3}\right)\end{array}$ \\
\hline $\mathrm{E}_{100} \mathrm{~V}_{100} \mathrm{Y}_{100} \mathrm{R}_{100}$ & 52.2 & 0.11 & 0.12 & $\mathrm{E}_{100} \mathrm{~V}_{100} \mathrm{Y}_{100} \mathrm{R}_{100}$ & 52.4 & 0.10 & 0.12 \\
\hline $\mathrm{E}_{75} \mathrm{VYR}$ & 49.0 & 0.11 & 0.12 & $\mathrm{E}_{75} \mathrm{VYR}$ & 48.8 & 0.11 & 0.13 \\
\hline $\mathrm{E}_{50} \mathrm{VYR}$ & 48.7 & 0.11 & 0.12 & $\mathrm{E}_{50} \mathrm{VYR}$ & 48.5 & 0.11 & 0.12 \\
\hline $\mathrm{E}_{25} \mathrm{VYR}$ & 48.5 & 0.12 & 0.13 & $\mathrm{E}_{25} \mathrm{VYR}$ & 48.2 & 0.11 & 0.12 \\
\hline $\mathrm{EV}_{75} \mathrm{YR}$ & 46.4 & 0.11 & 0.12 & $\mathrm{EV}_{75} \mathrm{YR}$ & 46.5 & 0.10 & 0.11 \\
\hline $\mathrm{EV}_{50} \mathrm{YR}$ & 46.0 & 0.11 & 0.13 & $\mathrm{EV}_{50} \mathrm{YR}$ & 46.2 & 0.10 & 0.12 \\
\hline $\mathrm{EV}_{25} \mathrm{YR}$ & 45.7 & 0.11 & 0.14 & $\mathrm{EV}_{25} \mathrm{YR}$ & 45.8 & 0.11 & 0.11 \\
\hline $\mathrm{EVY}_{75} \mathrm{R}$ & 44.5 & 0.10 & 0.11 & $\mathrm{EVY}_{75} \mathrm{R}$ & 45.9 & 0.10 & 0.11 \\
\hline $\mathrm{EVY}_{50} \mathrm{R}$ & 43.8 & 0.10 & 0.12 & $\mathrm{EVY}_{50} \mathrm{R}$ & 45 & 0.10 & 0.12 \\
\hline $\mathrm{EVY}_{25} \mathrm{R}$ & 43.0 & 0.10 & 0.14 & $\mathrm{EVY}_{25} \mathrm{R}$ & 44.2 & 0.10 & 0.13 \\
\hline $\mathrm{EVYR}_{75}$ & 49.0 & 0.11 & 0.14 & $\mathrm{EVYR}_{75}$ & 49.2 & 0.11 & 0.13 \\
\hline $\mathrm{EVYR}_{50}$ & 48.7 & 0.11 & 0.12 & $\mathrm{EVYR}_{50}$ & 48.8 & 0.11 & 0.12 \\
\hline $\mathrm{EVYR}_{25}$ & 48.4 & 0.11 & 0.13 & $\mathrm{EVYR}_{25}$ & 48.4 & 0.11 & 0.12 \\
\hline $\mathrm{E}_{0} \mathrm{~V}_{0} \mathrm{Y}_{0} \mathrm{R}_{0}$ & 0.8 & 0.00 & 0.00 & $\mathrm{E}_{0} \mathrm{~V}_{0} \mathrm{Y}_{0} \mathrm{R}_{0}$ & 0.5 & 0.00 & 0.00 \\
\hline
\end{tabular}

\section{Water Use Efficiencies}

WUE and IWUE values of the 2009 and 2010 years appeared differently in different treatments (Table 10). The maximum WUE values for 2009 year were found as 0.11 , $0.11,0.12-0.11,0.11,0.11 \mathrm{~kg} \mathrm{~mm}^{-1}$ and were found as $0.13,0.12,012-0.11,0.11,0.11 \mathrm{~kg} \mathrm{~mm}^{-1}$ from E75VYR, E50VYR, E25VYR and EVYR 75, EVYR $_{50}, \mathrm{EVYR}_{25}$ treatments for 2010 year, respectively. IWUE values for 2009 year were found as $0.12,0.12,0.13-0.14,0.12,0.13$ $\mathrm{kg} . \mathrm{mm}^{-1}$ and $0.13,0.12,0.12-0.13,0.12,0.12 \mathrm{~kg} \mathrm{~mm}^{-1}$ from E75VYR, E50VYR, E25VYR and EVYR 75 , $\mathrm{EVYR}_{50}, \mathrm{EVYR}_{25}$ treatments, respectively. When WUE and IWUE values were taken into consideration, the maximum WUE and IWUE values were obtained in establishment and ripening periods and the lowest value was obtained from vegetative and yield formation periods. In other words, the maximum yields were obtained from establishment and ripening periods and the most water was saved with deficit irrigation only in the establishment and ripening periods of the onion.

\section{Discussion}

In this experiment, irrigation treatments considerably influenced yield, bulb weight, diameter, height and dry matter. In both experimental years, the maximum amounts of water applied to the crop were 436-448 $\mathrm{mm}$ for from $\mathrm{E}_{100} \mathrm{~V}_{100} \mathrm{Y}_{100} \mathrm{R}_{100}$ while the seasonal evapotranspiration (ETa) values were changed between 496-205 $\mathrm{mm}$ and 502-
$210 \mathrm{~mm}$ for $\mathrm{E}_{0} \mathrm{~V}_{0} \mathrm{Y}_{0} \mathrm{R}_{0}$ treatment. Total water amounts varied from 350 to $550 \mathrm{~mm}$ for optimum yield (Doorenbos and Kassam, 1979). Ayas and Demirtas, (2009) reported that the maximum amounts of water applied to the crop was $362 \mathrm{~mm}$ in the $K 1_{c p}$ treatment while the minimum amount was $65 \mathrm{~mm}$ in the $K 5_{c p}$ treatment during the experimental year. The amount of water applied to other treatments ranged between 272 and $149 \mathrm{~mm}$ values. Seasonal evapotranspiration $\left(\mathrm{ET}_{\mathrm{a}}\right)$ was increased with the applied irrigation water and ranged from $95 \mathrm{~mm}$ to $372 \mathrm{~mm}$ for $K 5_{c p}$ and $K 1_{c p}$ treatments, respectively. Onion irrigation quantities applied to the treatments varied from 135.0 to $620.3 \mathrm{~mm}$ and seasonal evapotranspiration ranged from 350 to $450 \mathrm{~mm}$ in Isparta (Kadayifci et al., 2005). Orta and Şener, (2001) stated that the maintenance of soil moisture depletion level at 0.30 required $339.4 \mathrm{~mm}$ and $227.2 \mathrm{~mm}$ of irrigation water in 1997 and 1998, respectively. The seasonal evapotranspiration of onion was $420.0 \mathrm{~mm}$ in 1997 and $351.2 \mathrm{~mm}$ in 1998. The water requirements in Albacete (Spain) for optimum yield were $662 \mathrm{~mm}$ when using drip irrigation (Martin de Santa Olalla et al., 2004). Kumar et al., (2007) specified that microsprinkler-irrigated onions in India required between 257 and $468 \mathrm{~mm}$ of applied water and the crop evapotranspiration (ETc) were between 234-380 mm during the growing period. Ensico et al., (2009) reported that the seasonal crop water consumption was between 286 and $389 \mathrm{~mm}$.

The onion yield ranged between 52.2-0.8 and 52.4-0.5 t ha ${ }^{-1}$ for 2009 and 2010 years, respectively. Yield was 
decreased as the irrigation water amount reduced. According to the results of this experiment, the effect of deficit irrigation was founded significant on total yield. This result was compatible with those of studies (Doorenbos and Kassam, 1979; Orta and Şener, 2001; Kadayifci et al. 2005, Ayas and Demirtas, 2009).

Quality parameters such as fruit weight, diameter, height and dry matter have showed a similar response to deficit irrigation as determined at yield. As for bulb weight, there was influence of deficit irrigation on single bulb weight with respect to quality parameters. The bulb diameter and height have given similar response to deficit irrigation as it was observed in yield.

The highest quality parameters were obtained from $E_{100} V_{100} Y_{100} R_{100}$ treatments every two experiment years. The non-irrigated $\left(\mathrm{E}_{0} \mathrm{~V}_{0} \mathrm{Y}_{0} \mathrm{R}_{0}\right)$ treatment had lower values than all irrigation treatments. The result of study were agreement with (Doorenbos and Kassam, 1979; Chung, 1989; İmtiyaz and Singh, 1990; İmtiyaz et al., 1999; Orta and Şener, 2000; Kumar et al., 2007). Since $\mathrm{E}_{100} \mathrm{~V}_{100} \mathrm{Y}_{100} \mathrm{R}_{100}$ treatments have higher bulb weight than the other treatments, the lowest dry matters were found at $\mathrm{E}_{100} \mathrm{~V}_{100} \mathrm{Y}_{100} \mathrm{R}_{100}$ treatments when the highest dry matter values were observed at $E_{0} V_{0} Y_{0} R_{0}$ treatments in both years of the experiment. As a result, we may say that as the amount of irrigation water decrease, the number of dry matter increases. These values are similar to those of previous studies (İmtiyaz et al., 1999; Orta and Şener, 2001; Pelter et al., 2004; Kadayifci et al., 2004; Ayas and Demirtas, 2009).

The maximum WUE values for 2009 year were found as $0.11,0.11,0.12-0.11,0.11,0.11 \mathrm{~kg} \mathrm{~mm}^{-1}$ and were found as $0.13,0.12,012-0.11,0.11,0.11 \mathrm{~kg} \mathrm{~mm}^{-1}$ from E75VYR, E50VYR, E25VYR and EVYR 75, EVYR $_{50}$, $\mathrm{EVYR}_{25}$ treatments for 2010 year, respectively. IWUE values for 2009 year were found as $0.12,0.12,0.13-0.14$, $0.12,0.13 \mathrm{~kg} \cdot \mathrm{mm}^{-1}$ and $0.13,0.12,0.12-0.13,0.12,0.12$ $\mathrm{kg} \mathrm{mm}^{-1}$ from E75VYR, E50VYR, E25VYR and EVYR 75 , $\mathrm{EVYR}_{50}, \mathrm{EVYR}_{25}$ treatments, respectively. When WUE and IWUE values were taken into consideration, the maximum WUE and IWUE values were obtained in establishment and ripening periods and the lowest value was obtained from vegetative and yield formation periods.

When the results concerning WUE values compared with the findings of different researchers, they were in agreement with those of the other studies (Doorenbos and Kassam, 1979; Orta and Şener, 2001; Kadayifci et al., 2005; Bekele and Tilahun, 2007; Ayas and Demirtas, 2009; Bagali et al., 2012).

Water requirements for onions varies with location and irrigation system (Al-Jamal et al., 2001). As explained by Davis et al. (2008), it may be attributed to the variety and applied cultural practices handling under different climate and geographical conditions. Crop yield response factor $\left(\mathrm{k}_{\mathrm{y}}\right)$ for 2009 and 2010 year were calculated as 1.03 and 1.04 for onion, respectively. The specified values of $\mathrm{k}_{\mathrm{y}}$ (1.03-1.04) which is bigger than 1.00 shows that onion is susceptible to the water. Crop yield response factor $\left(\mathrm{k}_{\mathrm{y}}\right)$ also matches up with the values obtained by researchers who studied on similar issues (Doorenbos and Kassam, 1979; Orta and Şener, 2001; Kadayifci et al., 2005; Ayas and Demitas, 2009; Bagali et al., 2012 ).

\section{Conclusion}

According to the results of the study, irrigation water were applied 436 and $448 \mathrm{~mm}$ in $\mathrm{E}_{100} \mathrm{~V}_{100} \mathrm{Y}_{100} \mathrm{R}_{100}$ treatment applied of full irrigation in 2009 and 2010 years. The plant water consumption of onion was determined as 205-496 $\mathrm{mm}$ and $210-502 \mathrm{~mm}$ for $\mathrm{E}_{0} \mathrm{~V}_{0} \mathrm{Y}_{0} \mathrm{R}_{0}$ treatment 2009 and 2010 years.

Crop yield response factors $\left(\mathrm{k}_{\mathrm{y}}\right)$ for the different irrigation levels $\left(E_{100} V_{100} Y_{100} R_{100}, E_{75} V Y R, E_{50} V Y R\right.$, $E_{25} V Y R, E V_{75} Y R, \quad E V_{50} Y R, E V_{25} Y R, E V Y_{75} R, E V Y_{50} R$, $E V Y_{25} R, E V Y R_{75}, E V Y R_{50}, E V Y R_{25}, E_{0} V_{0} Y_{0} R_{0}$ treatments) in 2009 and 2010 years were calculated as 1.03 and 1.04 for onion, respectively. The factors of $\mathrm{k}_{\mathrm{y}}$ (1,03 and 1.04) values are bigger than 1,00 showed that the onion was susceptible to water. The crop yield response factors $\left(\mathrm{k}_{\mathrm{y}}\right)$ were close to each other in both years of the study. The highest yield decreases in all treatments were in $E_{0} V_{0} Y_{0} R_{0}$ treatments, while the lowest yield decreases were in $E_{100} V_{100} Y_{100} R_{100}$ treatments. In our experiment, it was studied out that irrigation treatments considerable influences yield, bulb diameter, weight, height and dry matter ratio.

In this study, it was studied out that irrigation applications considerably influences yield, bulb weight, diameter, height and dry matter. In both years of the study, the highest yield were $52.2 \mathrm{t} \mathrm{h}^{-1}$ and $52.4 \mathrm{t} \mathrm{h}^{-1}$ and it was observed in $\mathrm{E}_{100} \mathrm{~V}_{100} \mathrm{Y}_{100} \mathrm{R}_{100}$ treatment. The lowest yield were observed as $0.8 \mathrm{t} \mathrm{h}^{-1}$ and $0.5 \mathrm{t} \mathrm{h}^{-1}$ in $\mathrm{E}_{0} \mathrm{~V}_{0} \mathrm{Y}_{0} \mathrm{R}_{0}$ treatment. Yield decreased considerably as a result of the diminishment in the irrigation water. Relative yield decreases in the irrigation treatments in 2009 and 2010 were $6.5 \%, 7.2 \%, 7.6 \%, 12.5 \%, 13.5 \%, 14.2 \%, 17.3 \%$, $19.2 \%, 21.4 \%, 6.5 \%, 7.2 \%, 7.9 \%, 6425.0 \%$ and $7.4 \%$, $8.0 \%, 8.7 \%, 12.7 \%, 13.4 \%, 14.4 \%, 14.2 \%, 16.4 \%, 18.6 \%$, $6.5 \%, 7.4 \%, 8.3 \%, 10380.0 \%$, respectively. WUE and IWUE values of establishment and ripening periods were the maximum of all the treatments.

As a result, of a possible deficit irrigation in a semihumid climate condition, it is necessary to plan carefully and it is possible to say that the levels and times of the deficit irrigation were significantly effective on onion yield. If deficit irrigation treatment is obligatory, water deficiency should be planned only for establishment and ripening periods of onion. The water deficiency shouldn't be applied in vegetative and yield formation periods and irrigations in these periods should be exactly applied. In addition, in the irrigation planning to be applied in similar climatic conditions may be benefited from crop yield response factor $(\mathrm{ky})$ values. The results used to determine the amount of reduction in yield in response to the water deficiency applied to the plant may be used in studies related to onion. It can be recommended that establishment and ripening periods is most suitable periods for the deficit irrigation practices for onion irrigation by drip irrigation.

\section{References}

Al-Jamal MS, Ball S, Sammis, TW. 2001. Comparison of sprinkler, trickle and furrow irrigation efficiencies for onion production. Agricultural Water Management 46: 253-266.

Anonymous. 2005. The Annual Report of Meteorological Station, Bursa, Turkey. www.mgm.gov.tr/verideğerlendirme/il-veilceler-istatistic.aspx?k 
Anonymous. 2011a. The Annual Report of Meteorological Station, Bursa, Turkey. www.mgm.gov.tr/verideğerlendirme/il-ve-ilceleristatistic.aspx?k

Anonymous. 2011b. The Meteorological Station of Greenhouse Application Area, Yenişehir-Bursa, Turkey. www.mgm.gov.tr/verideğerlendirme/il-ve-ilceleristatistic.aspx?k

Anonymous. 2016. www.tarimorman.gov.tr/Issues/VegetativeProduction.

Ashraf SO and Ewees MSA. 2008. The possible use of humic acid incorporated with drip irrigation system to alleviate the harmful effects of saline water on tomato plants. - Fayoum J. Agric. Res. \& Dev. 22(1).

Ayas S and Demirtas C. 2009. Deficit irrigation effects on onion (Allium cepa L. E.T. Grano 502) yield in unheated greenhouse condition. Journal of Food, Agriculture \& Environment, 7 (3\&4): $239-243$.

Bagali AN, Patil HB, Guled MB, Patil RV. 2012. Effect of scheduling of drip irrigation on growth, yield and water use efficiency of onion (Allium cepa L.). Karnataka J. Agric. Sci.,25 (1): 116-119.

Bar-Yosef B, Sagiv B. 1982. Response of tomatoes to N and water applied via a trickle irrigation system. II Water. Argon. J., 74: 637-639.

Bekele S, Tilahun K. 2007. Regulated deficit irrigation scheduling of onion in a semiarid region of Ethiopia. Agricultural Water Management, 89: 148-152.

Bogle CR, Hartz TK, Nuntoez C. 1989. Comparison of subsurface trickle and furrow irrigation on plastic mulched and bare soil for tomato production. J. Am. Soc. Hortic. Sci., 114: 40-43.

Bos MG. 1980. Irrigation efficiencies at crop production level. ICID Bull.29: 18-25.

Büyükcangaz H, Demirtas C, Yazgan S, Korukcu A. 2007. Efficient water use in agriculture in Turkey: The need for pressurized irrigation systems, Water International, 32:sup1, 776-785

Chung B. 1989. Irrigation and bulb onion quality. ActaHorticulturae. No. 247: 233-237, 2 ref., Research and Development Conference on Vegetables, The Market and The Producer, Richmond, Australia.

Clough GH, Locasio SJ, Olsen SM 1990. The yield of successively cropped polyethylene mulched vegetables as affected by irrigation method and fertilization management. J. Am. Soc. Hortic. Sci. 115: 884-887.

Çakmak B, Gökalp Z. 2011. Climate change and effective water utilization. Journal of Agricultural Sciences Research. 4(1): 87-95.

Davis AR, Webber CL, Perkins-Veazie P, Ruso V, Lopez Galarza S, Sakata Y. 2008. A Review of production systems on watermelon quality. Roceedings of the IXth EUCARPIA Meeting on 98 Genetics and Breeding of Cucurbitaceae (M. PITRAT, editor), INRA, Avignon, France, 515-520.

Doorenbos J, Kassam AH. 1979. Yield response to water. FAO Irrigation and Drainage Paper No. 33, Rome.

Enciso J, Wiedenfeld B, Jifon J and Nelson S. 2009. Onion yield and quality response to two irrigation scheduling strategies. Scientia Horticulturae 120:301-305.

FAOSTAT. 2016. Food and Agriculture Organization Corporate Statistical Database. http://www.fao.org/faostat/en/\#data/QC

Günay A. 2005. Vegetable Growing, Vol I, ISBN.975-00725-29, İzmir,403-417.
Güngör Y, Yıldırım O (1989). Tarla Sulama Sistemleri. Ankara Üniversitesi Ziraat Fakültesi Yayınları No. 1155. 371s. Ankara, Turkey.

Hartz TK. 1993. Drip irrigation scheduling for fresh market tomato production. Hort. Science, 28: 35-37.

Howell TA, Yazar A, Scheneider AD, Dusek DA, Copeland KS. 1995. Yield and water use efficiency of corn in response to LEPA irrigation. Transaction of ASAE, Vol. 38 (6) 17371747.

Imtiyaz M and Singh SJ 1990. The effect of the soil moisture stress on onion: Evapotranspiration-yield relationship. In Salokhe, V.M. and Ilangantilike, S.G. (eds). Proceedings of the International Agricultural Engineering Conference and Exhibition, Bangkok, Thailand, December 1990, pp. 889898.

Imtiyaz M, Mgadla NP, Manase SK, Chendo K, Mothobi EO. 1999. Yield and economic return of vegetable crops under variable irrigation. Irrig. Sci. 19: 87-93.

Kadayifci A, Tuylu GI, Ucar Y. 2004. The effects of irrigation water salinity on bulb yield, plant water consumption and soil profile of onion plant. The Journal of Agriculture Science, (10-1) 45-49.

Kadayifci A, Tuylu GI, Ucar Y, Cakmak B. 2005. Crop water use of onion (Allium cepa L.) in Turkey. Agricultural Water Management 72 (2005) 59-68.

Kumar S, Imtiyaz M, Kumar A and Singh R. 2007. Response of onion (Allium cepa L.) to different levels of irrigation water. Agr. Wat. Manag. 89: 161-166.

Martin de Santa Olalla F, Dominguez-Padilla A and Lopez R. 2004. Production and quality of the onion (Allium cepa L.) cultivated under controlled deficit irrigation conditions in a semi-arid climate. Agr. Wat. Manag. 68: 77-79.

McNeish CM, Welch NC, Nelson RD 1985. Trickle irrigation requirements for stawberries in coastal California. J. Am. Soc. Hortic. Sci. 110: 714-718.

Orta AH and Şener M. 2001. A study on irrigation scheduling of onion. Journal of Biological Sciences. Vol. 1(8): 735-736.

Pelter GQ, Mittelstandt R, Leib BG, Redulla AC. 2004. Effects of water stress at specific growth stages on onion bulb yield and quality. Agr. Wat. Manag. 68: 107-115.

Ritchie JT, Johnson BS. 1990. Irrigation of agricultural crops. Agronomy Monograph, No 30: 363-390.

Sezen SM. 2005. Effects of drip irrigation management on yield and quality of field grown green beans. Agricultural Water Management, 71(2005)243-255.

Steel RGD, Torrie JH. 1980. Principles and procedures of statistics. A biometrical approach. McGraw-Hill, NewYork, pp.186-187.

Stewart JI, Misra RD, Pruitt WO, Hagan RM. 1975. Irrigating corn and sorghum with a deficient water supply. Trans. ASAE, 18: 270-280.

Van Straten G, Van Willingenburg G, Van Henten E, Van Ooteghem R. 2010. Optimum control of greenhouse cultivation. CRC Press, USA p.305.

Vural H, Eşiyok D and Duman İ. 2000. Culture Vegetables (Grow Vegetable). Horticulture Department, Faculty of Agriculture, Ege University, Bornova-İzmir, 440.

Yuan BZ, Sun J, Nishiyama S. 2003. Effect of drip irrigation on strawberry growth inside a plastic greenhouse. Biosystems Engineering, 87 (2): 237- 245.

Zhang H, Wang X, You M, Liu C. 1999. Water-yield relations and water-use efficiency of winter wheat in the North China Plain. Irrigation Science, v.19, p.37-45. 